\title{
RAZVOJ DUHANSKE STANICE U LJUBUŠKOM
}

\section{DEVELOPMENT OF TOBACCO PROCESSING PLANT IN LJUBUŠKI (BOSNIA AND HERZEGOVINA)}

\author{
Ljilja Rupčić*, Hrvoje Bartulović ${ }^{*}$
}

\begin{abstract}
Sažetak
Kompleks Duhanske stanice u gradu Ljubuškom građen je od 1880. godine u više faza za potrebe prerade duhana, koja je u to doba pa sve do početka 80-tih godina 20. stoljeća bila glavna gospodarska grana na području Ljubuškoga, ali i cijele Hercegovine. O tome svjedoče i ostale otkupne stanice u Čapljini, Širokom Brijegu, Grudama, Čitluku, Trebinju i Stolcu.

Na tadašnjoj južnoj periferiji grada Ljubuškoga, na parceli trapezoidnog oblika, smješteno je 11 objekata. U austrougarskoj fazi izgrađeno je pet paviljonskih zgrada - skladišta za duhan, daljnju klasifikaciju i obradu, jedna upravna zgrada i jedna stambena zgrada s nekoliko stanova za smještaj činovnika. U periodu Kraljevine Jugoslavije izgrađene su još 2 zgrade na sjevernom dijelu parcele, novo skladište i zgrada za fermentaciju duhana. Skladišne zgrade su 60-tih godina 20. stoljeća povezane mostovima na razini prvog kata radi lakšeg transporta duhana prema zgradi za fermentaciju. Upravo smještaj ovog kompleksa uzrokovao je razvoj područja koje danas predstavlja centar općine Ljubuški.

Visoka kvaliteta građevina, stupanj uređenosti vanjskog prostora i veličina sklopa svjedoče o značenju koji je kompleks imao. Radom je izrađena povijesna $i$ arhitektonsko-urbanistička analiza razvoja kompleksa sa svrhom valorizacije arhitektonsko-urbanističkih kvaliteta, što sve može poslužiti kao podloga za rad na daljnjim procesima revitalizacije ovog središnjeg gradskog prostora, koji ima potencijal generiranja novog urbaniteta grada Ljubuškog, ali i kao podloga za izradu analiza ostalih napuštenih otkupnih stanica po Hercegovini.
\end{abstract}

Ključne riječi: duhanska stanica, Ljubuški, Hercegovina

\footnotetext{
Sveučilište u Splitu, Fakultet građevinarstva, arhitekture i geodezije u Splitu, Matice hrvatske 15, 2100 Split

E-mail: ljilja.rupcic@gradst.hr; hrvoje.bartulovic@gradst.hr
} 


\begin{abstract}
The tobacco processing plant complex in town of Ljubuški was built in stages from 1880 on due to the growing needs of the tobacco processing industry, which has been the main economic industry in Ljubuški area, as well as in the whole of Hercegovina because similar plants were founded in Čapljina, Široki brijeg, Grude, Čitluk, Trebinje and Stolac.

In what was once the southern outskirts of Ljubuški, on a trapeze - shaped plot, in total 11 structures were situated. In the Austro-Hungarian phase five magazines were built - warehouses for tobacco and its further classification and processing, as well as one administrative building and one residential building for the purpose of accommodating management employees. During the period of the Kingdom of Yugoslavia additional two buildings were built in the northern part of the lot: a new warehouse and a new facility for tobacco fermentation, while the two remaining buildings were built after World War II. During the 1960s the warehouse buildings were connected with bridges on the first-floor level in order to facilitate tobacco transportation to the fermentation unit. The placing of this complex led to the development of area that represents today's centre of Ljubuški.

High quality of construction, the level of external space design and the mere size of the complex indicates its importance. This article aims to reveal the historical and architectural and urbanistic analysis of the complex in order to evaluate its architectural and urbanistic qualities, which can be used as a basis for further revitalization processes of this central urban space and could generate new urbanity for Ljubuški, but it can also be used as basis for developing analyses of the remaining tobacco processing plants in Hercegovina.
\end{abstract}

Key words: tobacco processing plant, Ljubuški, Hercegovina

\title{
1. Uvod
}

Kompleks Duhanske stanice u gradu Ljubuškom građen je od 1880 . godine u više faza za potrebe prerade duhana, koja je u to doba pa sve do početka 80-ih godina 20. stoljeća bila glavna gospodarska grana na području Ljubuškoga i cijele Hercegovine. Ipak, početkom 80-ih godina prošlog stoljeća slijedi naglo opadanje proizvodnje duhana na ovim prostorima te krajem 80-ih i početkom 90-ih godina prošlog stoljeća uzgoj duhana u Hercegovini doživljava krah. Ratna događanja 1992.-95. dodatno su utjecala na ukupno smanjenje proizvodnje duhana na području Bosne i Hercegovine. Po završetku ratnih zbivanja nastupili su neuspjeli pokušaji privatizacije duhanske industrije, što je na koncu dovelo do gašenja otkupnih stanica u Širokom Brijegu, Čapljini, Čitluku, Grudama, Ljubuškom, Mostaru, Ljubinju i Trebinju. Nepostojanje poljoprivrednih poticaja, slaba tehnološka razvijenost, kao i nepostojanje suvremenih sušionica i organiziranog otkupa uzrokovale su sve niže otkupne cijene duhana. Godine 2012. ugašena je i posljednja otkupna stanica u Stocu, čime 
je ukinuta i svaka mogućnost organiziranog i legalnog otkupa duhana na području Hercegovine. ${ }^{1}$

Danas Ljubuški nastavlja svoj gospodarski i kulturni oporavak i daljnji razvitak, u čemu napušteni prostori Duhanske stanice trenutno predstavljaju veliku zapreku, ali i ogroman potencijal za budući razvoj općine.

Radom je izrađena povijesna i arhitektonsko-urbanistička analiza razvoja kompleksa Duhanske stanice u Ljubuškom sa svrhom valorizacije arhitektonsko-urbanističkih kvaliteta, što sve može poslužiti kao podloga za rad na daljnjim procesima revitalizacije ovog središnjeg gradskog prostora koji ima potencijal generiranja novog urbaniteta grada Ljubuškog, ali i kao podloga za izradu analiza ostalih napuštenih otkupnih stanica po Hercegovini i smjernica za proces revitalizacije takve vrste napuštenih kompleksa.

\subsection{Duhanske stanice u Hercegovini ${ }^{2}$}

Duhanske stanice građene su u područjima gdje se intenzivno uzgajao duhan. One su bile poveznica između lokalnih obiteljskih proizvođača duhana i tvornica. Budući da je područje Hercegovine bilo izuzetno pogodno za kulturu duhana, na tom je području svojevremeno bilo aktivno devet duhanskih stanica. Nakon zaprimanja osušenog i od proizvođača relativno pripremljenog duhana tu se provodio otkup te daljnja manipulacija u vidu klasificiranja, sortiranja, skladištenja, fermentacije i pakiranja duhana radi daljnjeg transporta do tvornica.

Duhanske stanice na području Hercegovine stoga predstavljaju otkupno proizvodne sklopove, velikih površina, sačinjenih od većeg broja slobodnostojećih građevina. U pravilu, stanice su imale administrativne zgrade za stručno osoblje, više skladišta u kojima se vršila obrada i fermentacija duhana, servisne građevine u vidu nužnika, kupaonica, konjušnica, pomoćnih baraka i sl. Neke od stanica su imale kantine te stambene zgrade sa nekoliko stanova za smještaj činovnika. Unutar obuhvata često su se nalazile pokazne plantaže, gdje bi stručno osoblje, pristiglo većinom iz stranih zemalja, pokazivalo sadiocima kako pravilno pristupiti uzgoju kulture duhana. Najprepoznatljivi elementi unutar sklopova stanica bila su longitudinalna skladišta, različite katnosti, s dvostrešnim krovovima. Obuhvati stanica su u pravilu bili ograđeni prepoznatljivim kamenim zidovima [2].

\footnotetext{
1 O važnosti duhanske industrije za razvoj hercegovačkog kraja ukazuje međunarodni znanstveno-stručni skup „Duhan u Bosni i Hercegovini - jučer, danas i sutra“ održan u Mostaru, 2. - 3. listopada 2017. godine. Za opširniji pregled vidi [1].

2 Međuodnos tehnološkog procesa otkupa i obrade duhana i prostorne organizacije duhanskih stanica na području Hercegovine istražen je u članku autora I. Vukojević, J. Beljo i Z. Barišić Marenić pod nazivom „UTJECAJ TEHNOLOGIJE OBRADE DUHANA NA PROSTORNU ORGANIZACIJU DUHANSKIH STANICA NA PODRUČJU HERCEGOVINE“ te su u ovom poglavlju citirani određeni dijelovi teksta; za detaljnije vidi: [2]
} 


\section{Analiza razvoja Duhanske stanice u Ljubuškom}

\subsection{Povijesni razvoj Duhanske stanice u Ljubuškom}

Izgradnja sklopa Duhanske stanice u Ljubuškom započela je 1878. godine, a Duhanska stanica otvorena je 1880. godine. Stanica je smještena u podnožju brda Butorovice i utvrde Hercega Stjepana na tada gotovo neizgrađenom području. Lokacija je predstavljala periferiju tadašnjeg grada koji se do tada razvijao na južnim padinama Butorovice (Slika 1). Tijekom 19. stoljeća, pod Austrougarskom aneksijom BiH, centar grada se postupno izmjestio u podnožje brda te danas Duhanska stanica predstavlja centralni prostor gradskog tkiva.

U prvoj, austrougarskoj fazi izgrađeno je pet magazina (skladišta za duhan, daljnju klasifikaciju i obradu), jedna upravna zgrada i jedna stambena zgrada s nekoliko stanova za smještaj činovnika. Prvo su sagrađena četiri skladišta za duhan pravilnog pravokutnog tlocrta dimenzija oko $43 \times 15 \mathrm{~m}$, s $3-4$ etaže i korisnim potkrovljem (katnosti $\mathrm{P}+2 / 3+\mathrm{Pk})$ te je ubrzo na istoku parcele dodan i peti magazin. $\mathrm{Na}$ situacijskom nacrtu iz 1891. godine zabilježeno je postajanje tri perivojno uređena dijela parcela koje nisu sačuvane, a unutar sklopa nalazio se kameni bunar za vodu za piće. Možemo ustvrditi onodobni visoki interes za uređenje gradskih prostora za grad u nastanku (Slika 2). Na ovom nacrtu nije vidljiva druga upravna zgrada, izgrađena nešto kasnije na području jugozapadnog perivoja (Slika 3).

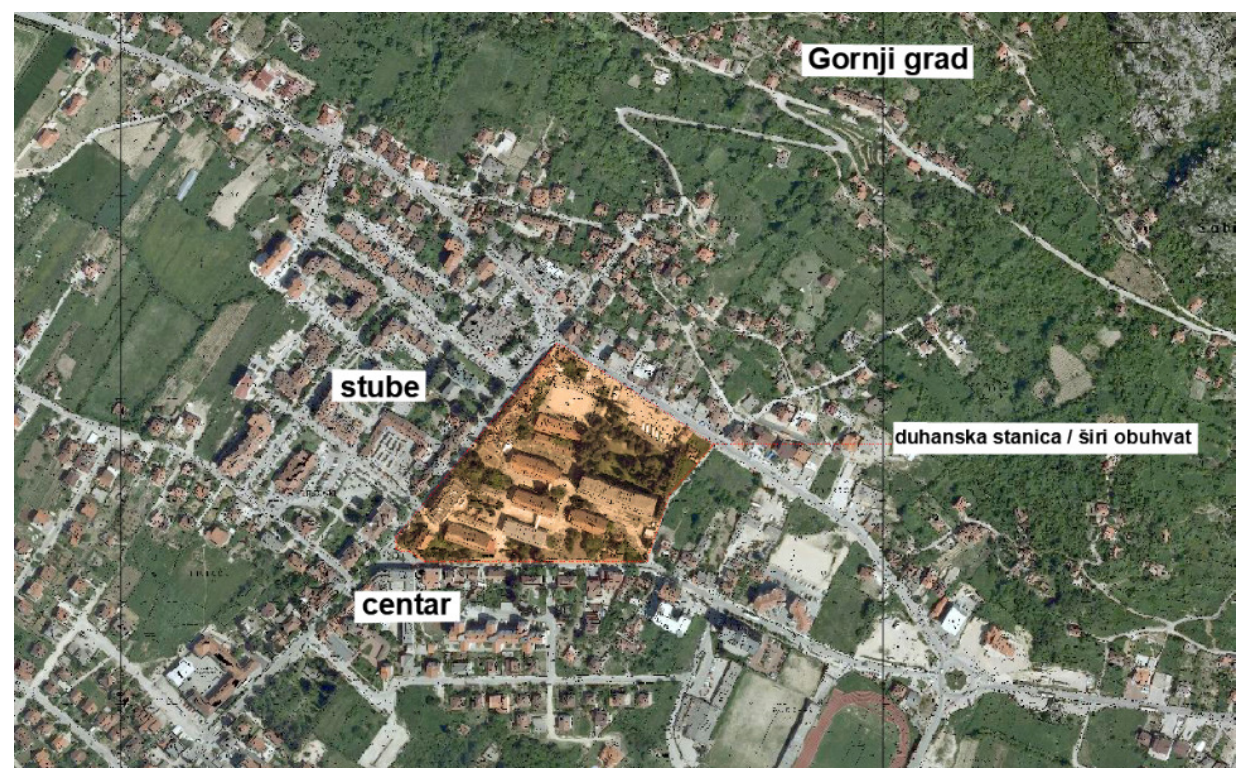

Slika 1. Duhanska stanica Ljubuški, ortofoto, 2010. [prilagođeno prema 3] 


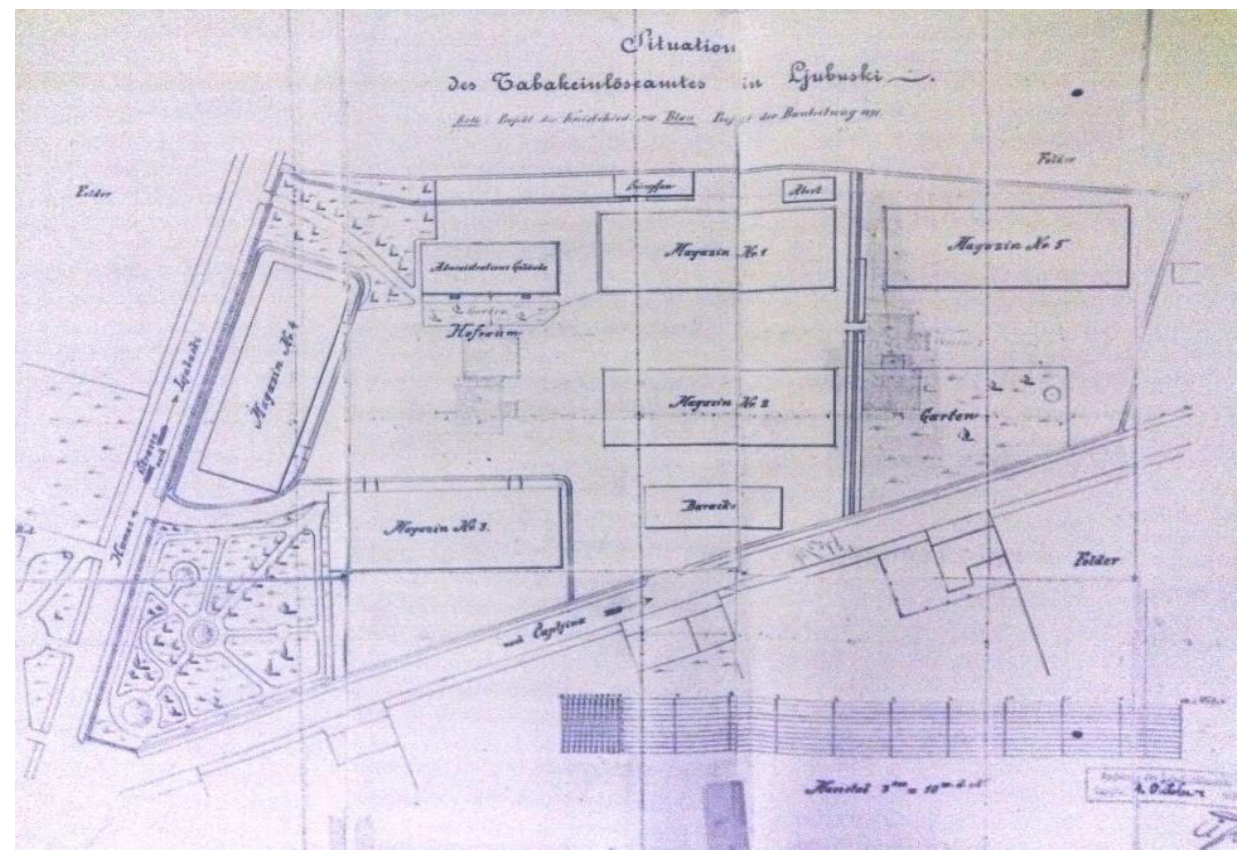

Slika 2. Situacijski nacrt Duhanske stanice Ljubuški iz 1891. godine [prilagođeno prema 4]

Lijubuški od sjeverne strane.

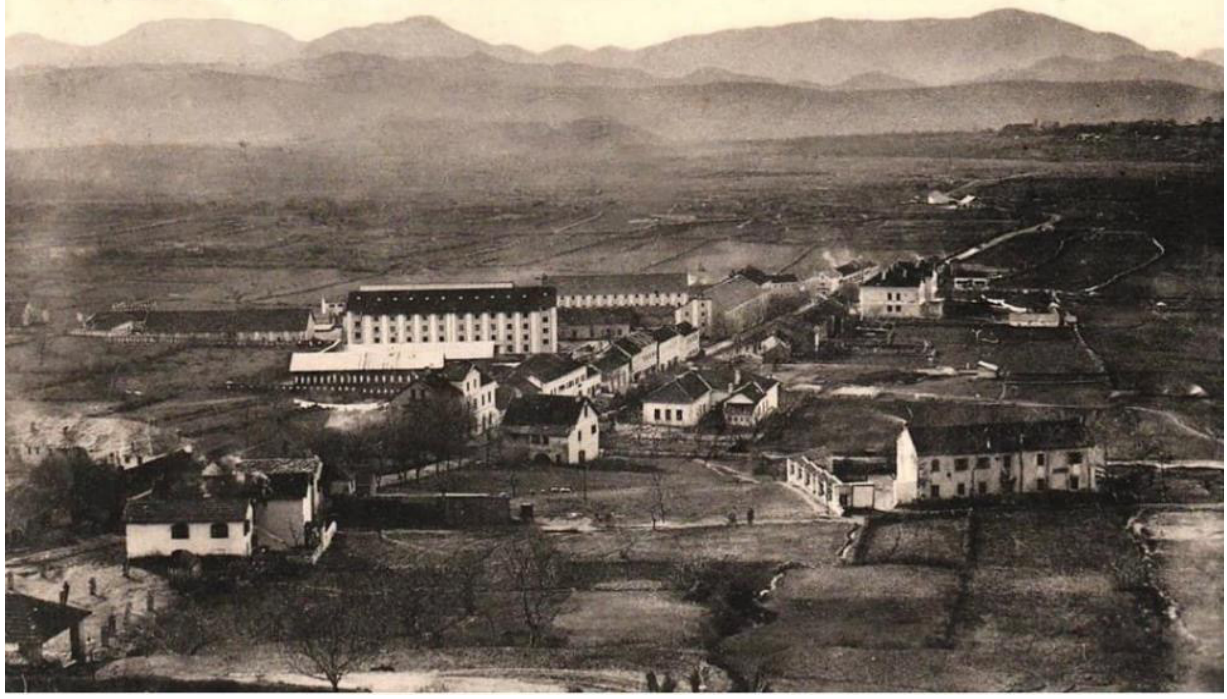

Slika 3. Pogled na Duhansku stanicu Ljubuški, fotografija iz 1908. godine [5] 
U periodu Kraljevine Jugoslavije izgrađene su još dvije zgrade, proširujući time kompleks prostorno prema sjeveru. Radi se o jednom novom magazinu i jednoj pomoćnoj građevni. Novi magazin tlocrtno je vrlo sličnog oblika kao magazini iz prve faze, uz iznimku formiranja komunikacijskih jezgri van osnovnog volumena na obje kraće stranice. Također, ovaj magazin viši je za jedan kat od prethodnih magazina, odnosno ima 4 etaže i korisno potkrovlje (katnost $\mathrm{P}+3+\mathrm{Pk}$ ).

U zadnjoj fazi proširenja kompleksa, poslije Drugog svjetskog rata, izgrađena je najveća građevina na lokaciji. Radi se o sedmom magazinu, koji je imao pet korisnih etaža (katnost $P+4$ ) tlocrtne površine oko $1450 \mathrm{~m} 2$, što je više nego dvostruko od tlocrtne površine etaža prethodnih magazina. Ova je zgrada služila za fermentaciju duhana. Tu se duhan odlagao na specijalizirane police, gdje bi kroz nekoliko mjeseci, najčešće od ožujka do srpnja zbog povoljnih mikroklimatskih prilika, mogao fermentirati (Slika 4).

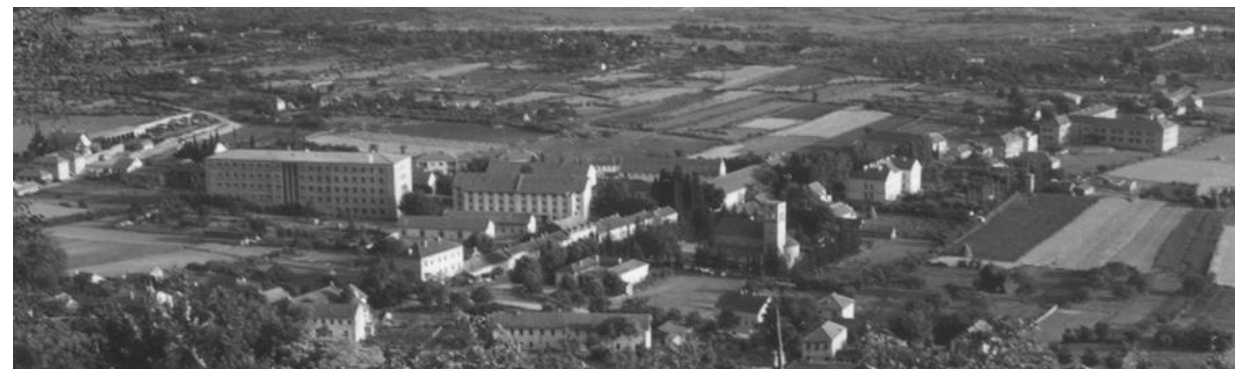

Slika 4. Pogled na Duhansku stanicu Ljubuški, fotografija iz 1958. godine [5]

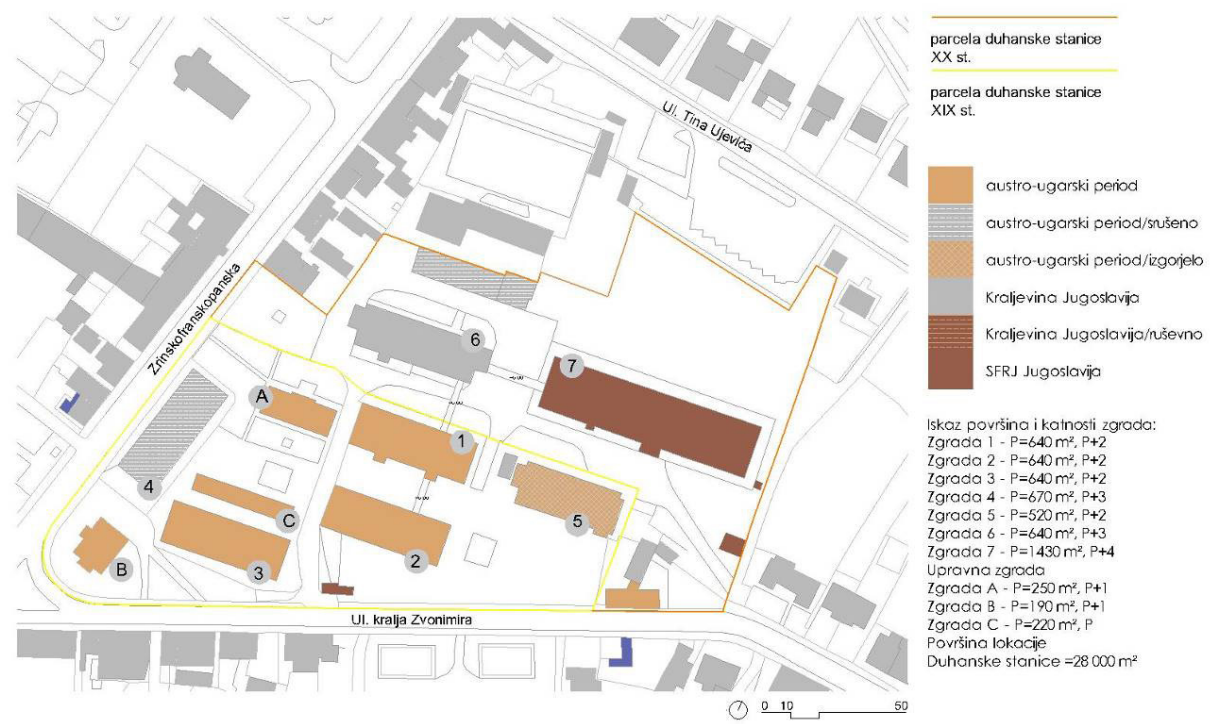

Slika 5. Povijesna analiza i katnost zgrada [prilagođeno prema 3] 
Potaknuti promjenama u procesu prerade duhana, gotovo sve skladišne zgrade kompleksa su 1960-ih povezane mostovima na razini prvog kata radi lakšeg transporta duhana prema sedmom magazinu, odnosno zgradi za fermentaciju. Ovim intervencijama je kompleks dobio još jedan specifičan sloj prepoznatljivosti te zanimljiv suodnos novog elementa $\mathrm{s}$ postojećim zgradama.

\subsection{Urbanističke postavke kompleksa}

Na parceli trapezoidnog oblika smješteno je ukupno 11 objekata koji su građeni u fazama (Slika 5). Većina zgrada je postavljena paralelno jedna prema drugoj s dužim stranicama položenim u smjeru jugoistok sjeverozapad. Time zgrade odstupaju od smjera južne obodne prometnice i ostatka gradskog tkiva, koji uglavnom gradnjom prati regulacijske linije ulica. Iznimku čine postava četvrtog magazina i zgrade B, koje su svojim dužim stranicama postavljene paralelno s obodnom ulicom. Time se dobila jedna zanimljiva urbanistička kompozicija, jasno prepoznatljiva unutar gradske strukture. Ujedno su formirani i zanimljivi međuprostori između građevina, dodatno uokvireni izvedbom spojnih mostova na razini prve etaže. $^{3}$

Katnošću i tlocrtnim gabaritima objekti su primjerni mjerilu grada Ljubuški, izuzev sedmog magazina koji se ističe volumenom. S obzirom da se kompleks unutar grada Ljubuškog doživljava kao jedinstvena zasebna cjelina, možemo ga okarakterizirati samodostatnim u vidu formiranja urbanističke slike grada.

Cijeli obuhvat Duhanske stanice ograđen je prepoznatljivim visokim kamenim zidovima prema susjednim česticama, nižim kamenim zidom s kovanom ogradom prema današnjoj ulici kralja Zvonimira te manje reprezentativnim ogradama prema preostalim obodima. Visoka kvaliteta građevina, stupanj uređenosti vanjskog prostora i veličina sklopa svjedoče o značenju koji je kompleks imao kroz povijest.

\subsection{Tipologija zgrada}

U sklopu duhanske stanice postoje tri vrste tipologije magazina koji su imali funkciju skladišno-prerađivačkih zgrada.

\subsubsection{MAGAZINI 1, 2, 3, 4 i 5}

Za vrijeme Austrougarske najprije su sagrađena četiri skladišta za duhan. Sve zgrade imale su primarno skladišnu funkciju, a dodatno bi se u prizemlju magazina br. 2 i 3 vršilo vaganje i otkup duhana od lokalnih

\footnotetext{
3 Odstupanje od urbanističke matrice i stvaranje karakterističnih ambijenata može se pronaći u urbanističko-arhitektonskom sklopu duhanske stanice „Vaga“ u Metkoviću; za detaljnije vidi: [9]
} 
proizvođača. Skladišta su identičnog pravilnog tlocrtnog oblika izduženog pravokutnika (omjer 1:3) dimenzija 43x15m, različite katnosti: P+2 i P+3 s plitkim dvostrešnim krovovima sa sljemenom položenim po dužoj strani. Karakteriziraju ih kontinuirani obodni zidani zidovi i otvoreni plan, omogućen drvenim i/ili drveno željeznim skeletnim sustavima $\mathrm{u}$ vidu četveroreda rastera stupova (dva reda bila su prislonjena uz obodne zidove) na koje se oslanjana drvena međukatna konstrukcija. Potkrovlje je definirano drvenim dvostrešnim krovištem te je služilo kao dodatni skladišni prostor. Vanjštinu zgrade obilježavaju kameni zidovi sa strukturom ojačanja (zidnog zadebljanja) i ritam modularnih prozora. Visina katnih etaža zgrade za skladište duhana iznosila je oko 2,80 m, što se jasno čita na eksterijeru u vidu identičnih kvadratničkih katnih prozora smještenih u sredini uspostavljenog rastera stupova (Slika 6). Na ovaj su način skladišta imala prilično velik udio otvorenosti pročelja, što je bilo nužno za provjetravanje i regulaciju temperature unutar skladišta te se na takav način moglo donekle utjecati na vlažnost duhana, odnosno proces sušenja. ${ }^{4}$

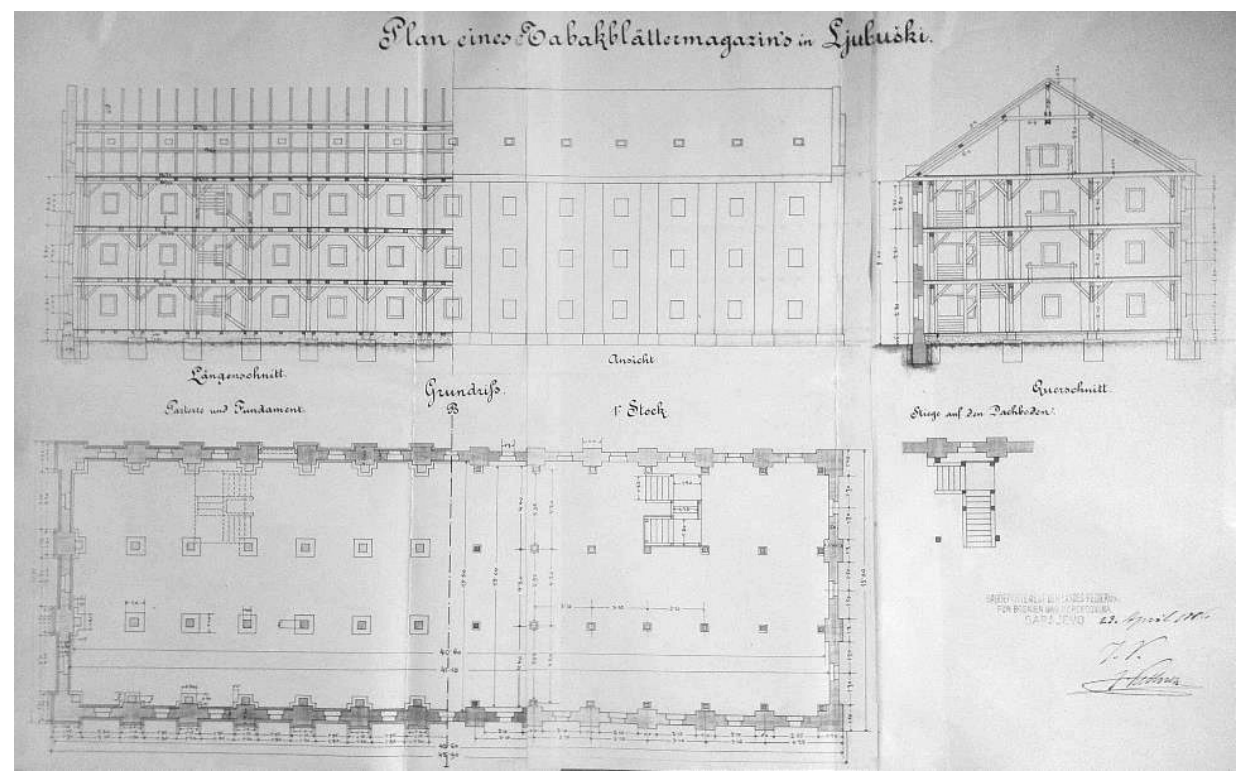

Slika 6. Nacrti tipskih magazina iz 1886. godine. Po ovom tipskom projektu su izgrađene zgrade skladišta i u stanicama duhana u Čapljini i Širokom brijegu [6]

$\overline{4}$ Iz trenutnog stanja evidentno je da su sve zgrade naknadno žbukane, nije poznato kada. 


\subsubsection{MAGAZIN 6}

Za vrijeme Kraljevine Jugoslavije sagrađen je šesti magazin, koji je tipologijom sličan skladištima sagrađenim za vrijeme Austro-Ugarske. Ponovno se radi o kontinuiranim obodnim zidanim zidovima i otvorenim planom omogućenim četveroredom rastera stupova. Gabaritno vrlo sličnih tlocrtnih dimenzija, oko 43 x 15 m, ova zgrada se od prvih skladišta razlikuje u komunikacijama koje su smještene sa strana zgrade, na istočnoj i zapadnoj fasadi, u posebnom bloku. Krov je također dvostrešan, sa sljemenom položenim paralelno s dužom stranicom, te završava na zabatnim trokutnim krajevima zidova. Katnost ovog magazina je $\mathrm{P}+3$, a visina etaže jest 2,80 m (Slika 7). Međukatna i krovna konstrukcija bile su drvene. Komunikacijski blok bio je napravljen od kamenih stepeništa i podesta te je ostao očuvan do danas.

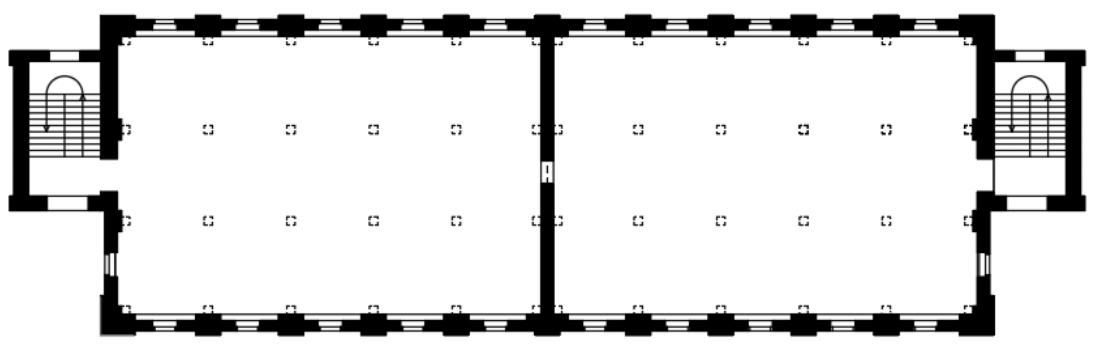

Slika 7. Tlocrt šestog magazina (Lj. Rupčić)

\subsubsection{MAGAZIN 7}

1948. godine izgrađen je posljednji i najveći objekt kompleksa - sedmi magazin. U oblikovnom i organizacijskom smislu riječ je o znatno većem skladištu od ranije sagrađenih, ukupne katnosti $\mathrm{P}+4+\mathrm{Pk}$ i tlocrtne površine jedne etaže oko $1450 \mathrm{~m}^{2}$.

S obzirom da ovaj magazin ima veću visinu etaža te znatno veće tlocrtne gabarite (pravokutnik dimenzija oko 19x77m), zgrada se ističe unutar kompleksa svojom pojavnošću. Za razliku od ostalih, međukatna konstrukcija i nosivi stupovi ovog magazina su od armiranog betona te $\mathrm{j}$ konstrukcija ostala sačuvana kroz godine. Specifičan je dizajn koji koristi armirano-betonske "gljivaste“ stupove s proširenim kapitelima raspoređenima u rasteru $6,3 \times 6,7 \mathrm{~m}$. Funkcionalna organizacija također je drugačija jer je tlocrt podijeljen na tri dijela: manji radni prostor istočno, veći radni prostor zapadno, a po sredini zgrade smješten je komunikacijski blok s vertikalnim teretnim dizalom. Ova podjela jasno se iščitava u vanjskom oblikovanju s tri različite vrste fenestracije: identičnim izduženim pravokutnim otvorima postavljenim u rasteru na zapadnom 
dijelu objekta, a koji se pretvaraju u svojevrstan triptih u središnjoj zoni i na zabatima objekta, te upola manjim pravokutnim prozorima na istočnom dijelu, postavljenim u istom ritmu kao i na zapadu. Uz navedeno, vanjsko oblikovanje definirano je vidljivim ziđem od klesanog kamena (zanimljivom kombinacijom pravilno i nepravilno isklesanih oblika) te horizontalnim potezima armiranobetonskog vijenca u razini međukatne konstrukcije. Krov je četverostrešan i postavljen geometrijskom raspodjelom identičnog nagiba krovnih ploha (Slika 8).
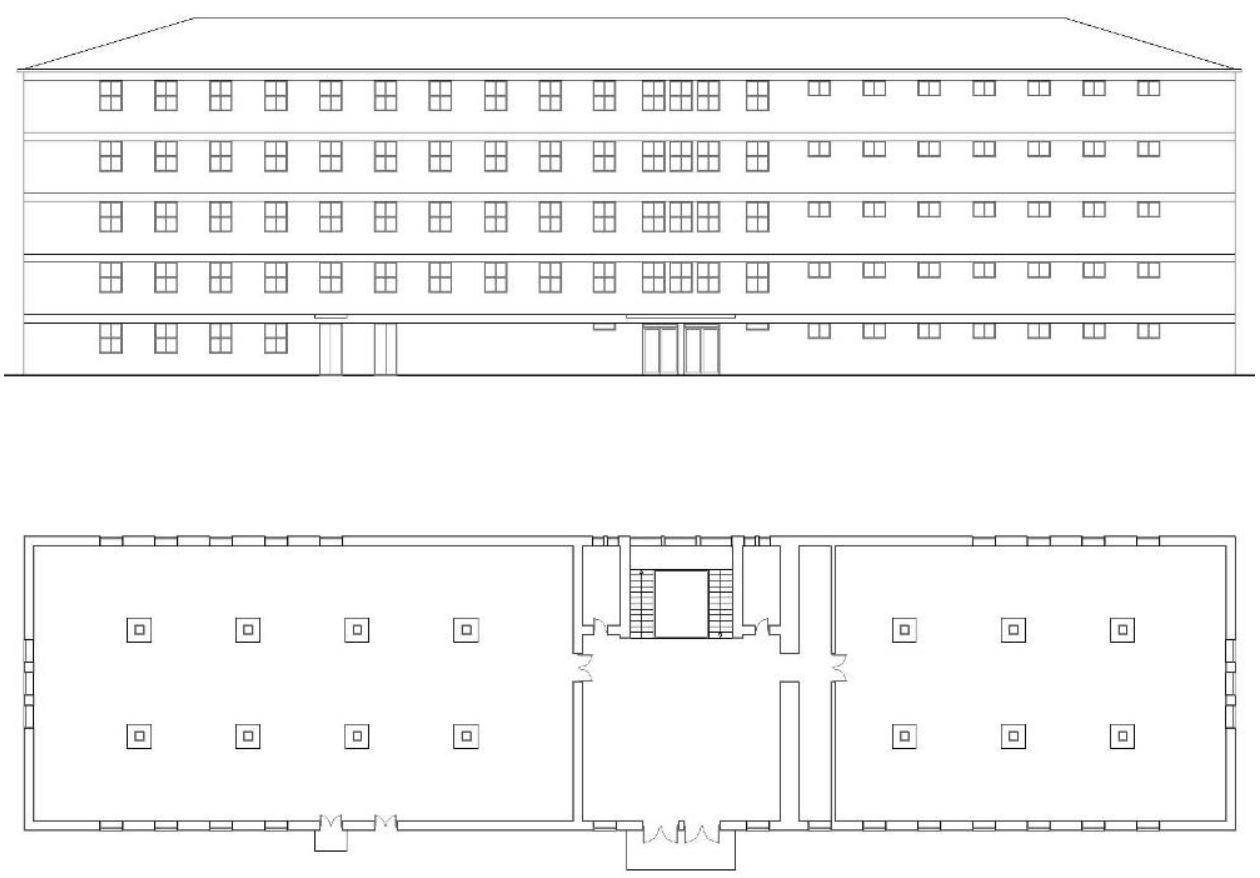

Slika 8. Arhitektonski snimak zgrade Magazina br. 7 (Lj. Rupčić)

Sve tri analizirane tipologije magazina karakterizira jasno postavljena arhitektonska koncepcija skeletnog sustava i zidanih obodnih zidova s unificiranom fenestracijom. Također, sva tri tipa pokazala su fleksibilnost u korištenju i prilagodljivost promjenama tehnike procesa prerade duhana, što je posebice vidljivo u izvedbi spojnih mostova između 2. i 1. , 1. i 6 . i 6. i 7. magazina na razini prvog kata, čime su se zapravo ove četiri zgrade pretvorile $u$ jedinstvenu funkcionalnu jedinicu. 


\subsection{Zatvaranje Duhanske stanice i trenutno stanje}

Cijeli kompleks Duhanske stanice prestao je s radom 1980. godine. Uslijedio je niz godina nekorištenja i neodržavanja, što je dovelo do prodora atmosferilija te, posljedično, do propadanja pojedinih građevnih elemenata zgrada (kao što su prozori, vrata i slično) i do urušavanja gotovo svih drvenih konstruktivnih elemenata.

Ovaj, za Ljubuški, velebni kompleks postao je ruglo ovog grada. Tijekom godina bilo je pokušaja revitalizacije prostora. Tako je udruga „Alternativna Liga“, dobivši dopuštenje od tadašnjih vlasnika, 2008. godine očistila i adaptirala određene prostore sedmog magazina u kojem su organizirali niz izložbi, predstava, koncerata i humanitarnih akcija. ${ }^{5}$

No, početkom 2011. godine požar je izbio u Magazinu br. 5, pri čemu se od požarnih oštećenja urušio krov zgrade. Navedeni incident ukazao je na opasnosti korištenja kompleksa u zatečenom stanju te su u njemu prekinute sve društvene aktivnosti (Slika 9, 10, 11).

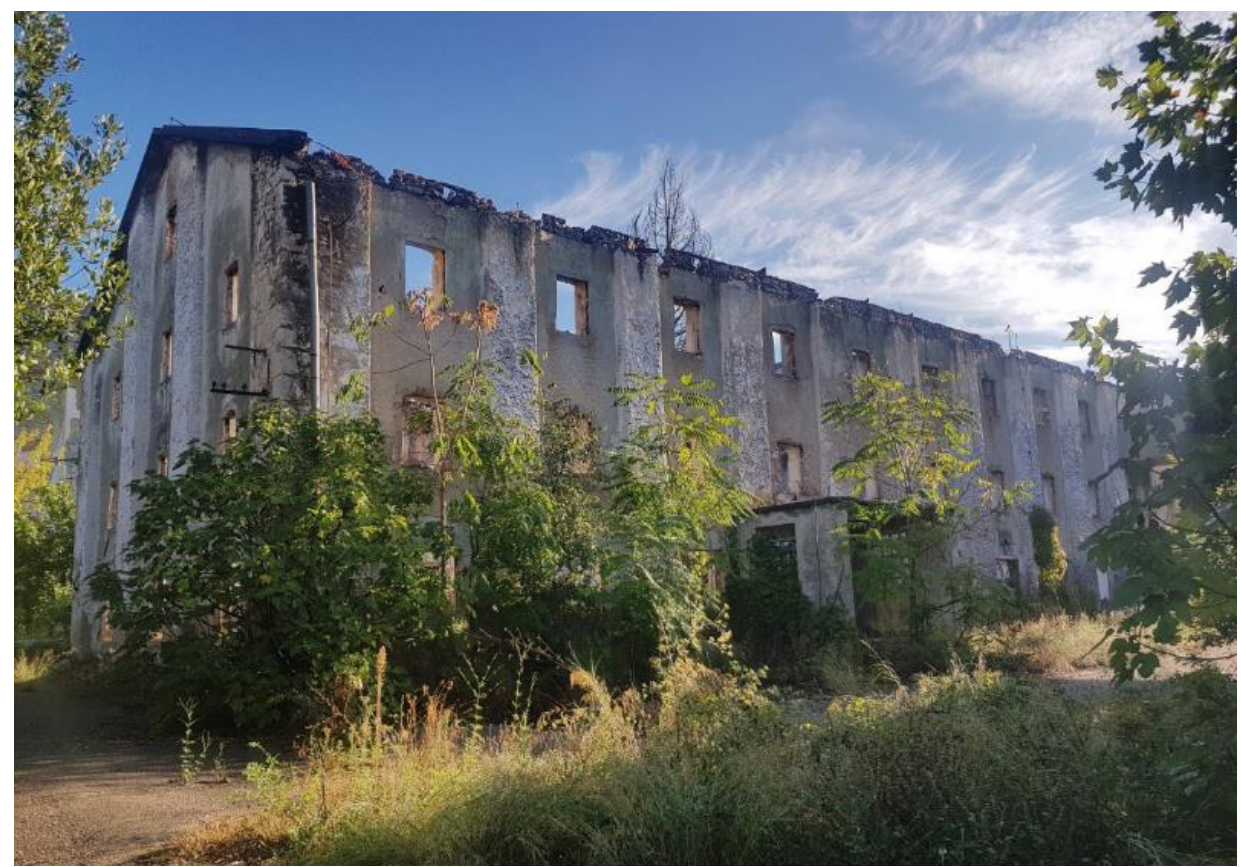

Slika 9. Pogled na Magazin br. 1. (Foto: Lj. Rupčić)

5 Udruga „Alternativna liga početkom 21. stoljeća je poduzimala određene aktivnosti na kulturnoj sceni i doprinosila na humanitarnom planu Ljubuškoga. Udruga je djelovala u prizemlju nekadašnjeg 7. magazina duhanske stanice u centru Ljubuškog. Prostor je dobila na korištenje od tvrtke Agroprom, a dopuštenje od tadašnjeg vlasnika, Agencije za privatizaciju. Tako su u klubu nazvanom "Krchivrat" u sklopu Duhanske stanice gostovali umjetnici iz BiH, Hrvatske, Makedonije, Njemačke, Brazila [8]. 
O potencijalu prostora Duhanske stanice svjedoči i prostorno-planska dokumentacija. Unutar važeće prostorno-planske dokumentacije [9], prostor Duhanske stanice ima status zaštićenog područja. Naveden pod oznakom Z228, uvršten je u III. stupanj zaštite. III. stupanj zaštite imaju svi evidentirani lokaliteti i spomenici kulturno-povijesnog naslijeđa na području Općine, a koji su od lokalnog značenja. Odlukom o provođenju određuje se njihova zona zaštite i uvjeti djelovanja unutar zone zaštite. Prema namjenama, u centru općine predviđena je izgradnja svih centralnih sadržaja i objekata društvene infrastrukture primjerenih općinskom sjedištu. ${ }^{6}$

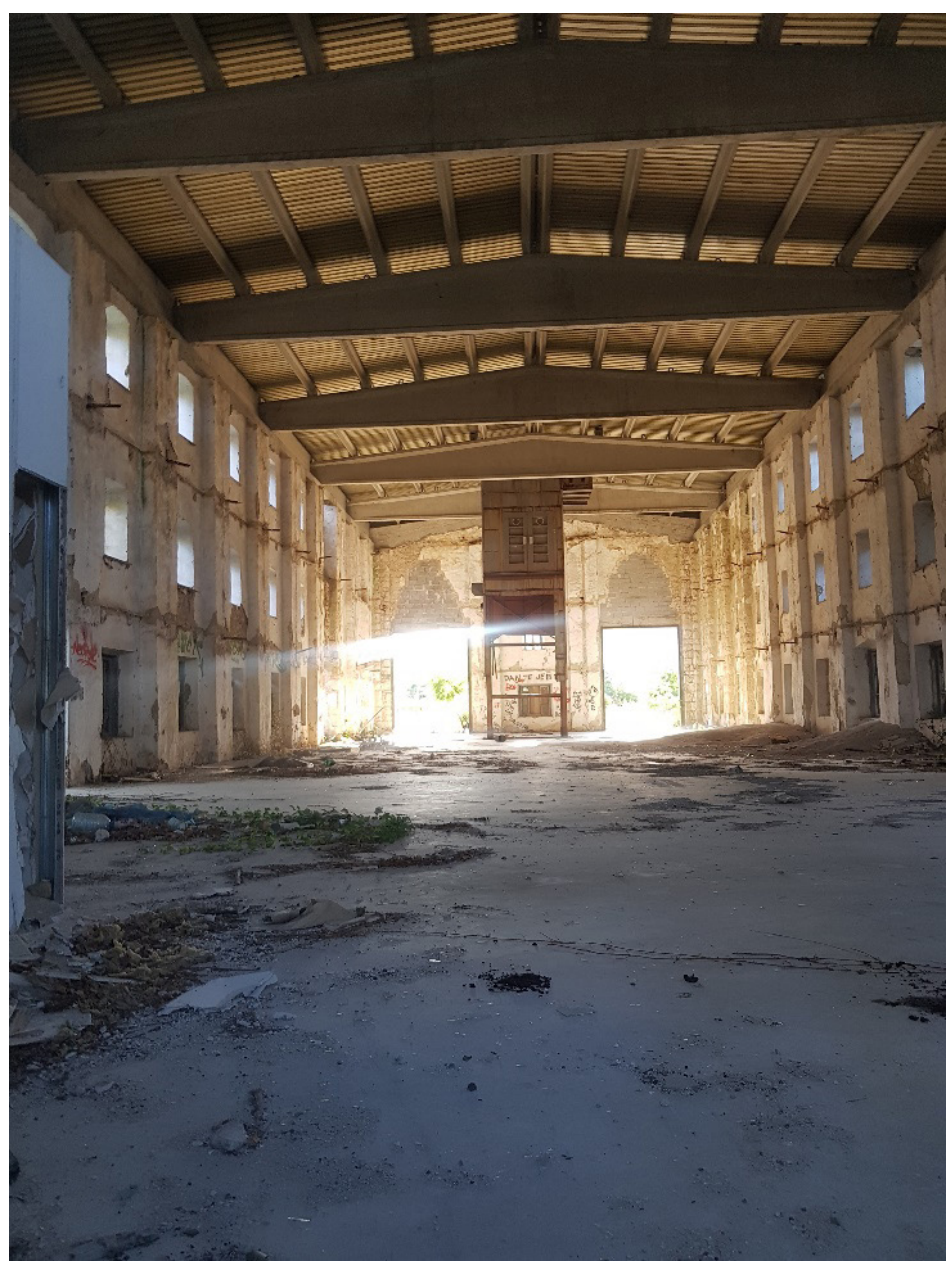

Slika 10. Unutrašnjost Magazina br. 2. (Foto: Lj. Rupčić)

\footnotetext{
6 Lokacija Duhanske stanice trenutno je rascjepkana na nekoliko vlasnika, od Županije Zapadnohercegovačke županije, do Općine Ljubuški i nekolicine privatnika. Zbog takve necjelovite raspodjele, prostorni plan za ovu zonu nije detaljnije određen.
} 


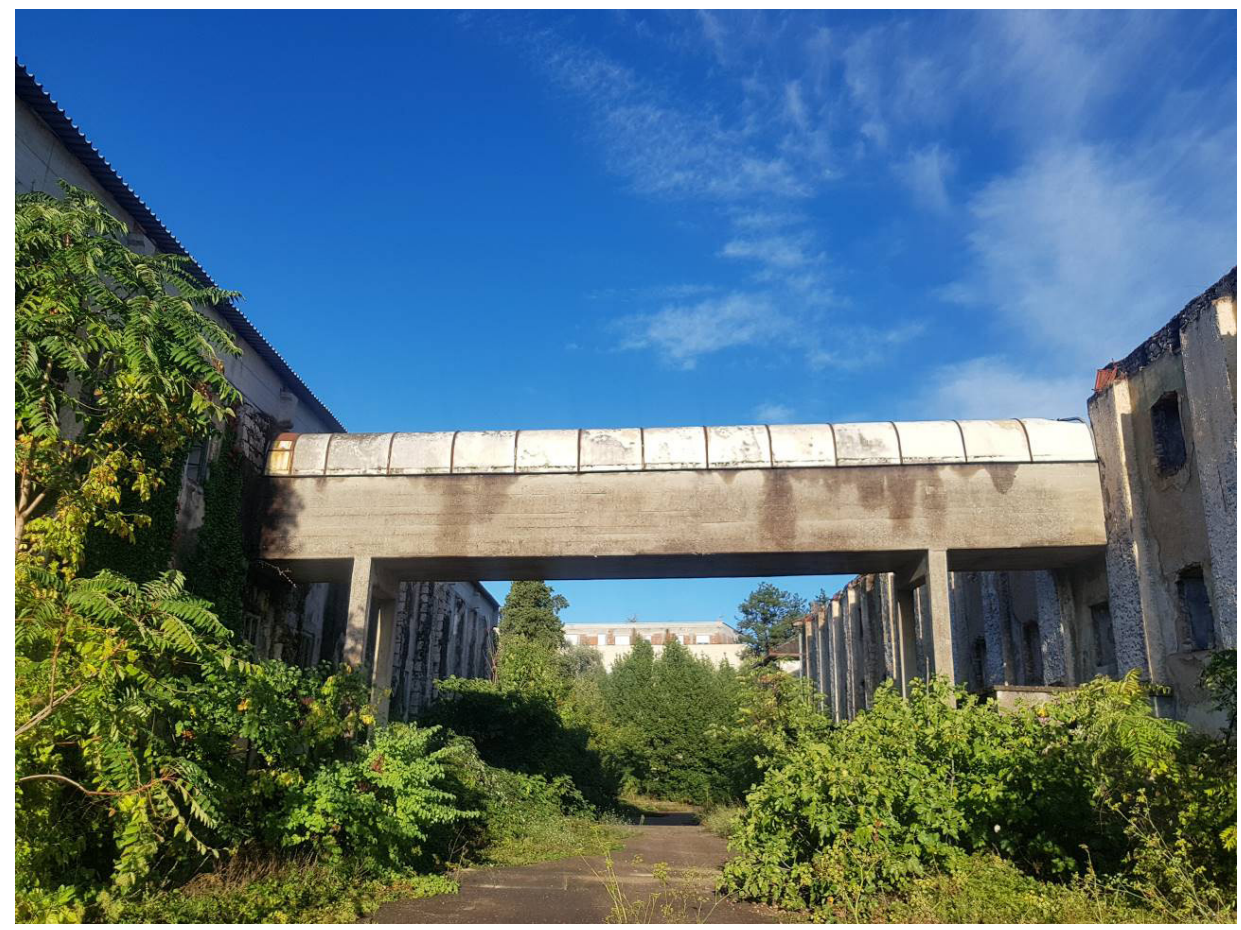

Slika 11. Pogled na most između prvog i drugog magazina (Foto: Lj. Rupčić)

\subsection{Diplomski rad - Prenamjena prostora bivše Duhanske stanice u Ljubuškom [10]}

Tema diplomskoga rada, u sklopu kojeg je rađeno preliminarno istraživanje za ovaj članak, bila je revitalizacija Duhanske stanice u Ljubuški pod nazivom „Duhansko blago“. Projektnim nazivom nastojalo se ukazati na skriveni potencijal lokacije. Planiranom prenamjenom Duhanske stanice u kulturno-društveni centar cilj je bio očuvati prostor koji će svjedočiti o važnosti i značaju duhana kao gospodarske grane koja je u prošlosti bila glavna nositeljica života skoro svih stanovnika općine Ljubuški, ali i dati kompleksu novi značaj u suvremenom životu Ljubuškoga. Na atraktivnoj lokaciji, u samom središtu grada, planiran je smještaj Muzeja duhana, gradske knjižnice, dječjeg vrtića i niza dodatnih društvenih i kulturnih sadržaja koji su prijeko potrebni gradu. Tu bi bile i prostorije za mlade i udruge koje djeluju u gradu i okolici, a nemaju svoje prostore, prostori glazbene i plesne škole, multifunkcionalne kino dvorane i ostali popratni sadržaji. U skladu s odabranim programom ispitane su mogućnosti smještanja pojedinog sadržaja unutar postojećih građevina te je tako Muzej Duhana smješten u Magazin br. 7, knjižnica u Magazin br. 6, glazbena škola 
u Magazin br. 1, plesna škola i dvorana u Magazin br. 5, multifunkcionalna kino dvorana u Magazin br. 2, a prostori za sportske klubove u Magazin br. $3^{7}$ (Slika 12). Svaki od navedenih sadržaja, uz sve potrebne tehničke i pomoćne prostorije za funkcioniranje objekta, bi bio obogaćen dodatnim sadržajima javno-društvenog karaktera. Tako bi u zgradi muzeja, uz stalni postav o duhanu, bio predviđen prostor za povremene izložbe i suvenirnica; uz novu knjižnicu tu bi našla svoje mjesto knjižara, kafić i informatička prostorija za osnovnoškolce i srednjoškolce; uz prostor za sportske klubove prostori sportsko-adrenalinskog karaktera poput teretana, stijene za penjanje i slično; uz plesnu školu prostori kulturno-umjetničkog društva, itd.

U prostorima nekadašnje zgrade stanova za radnike smjestili bi se prostori udruga, a u prostorima upravne zgrade uredi općine.

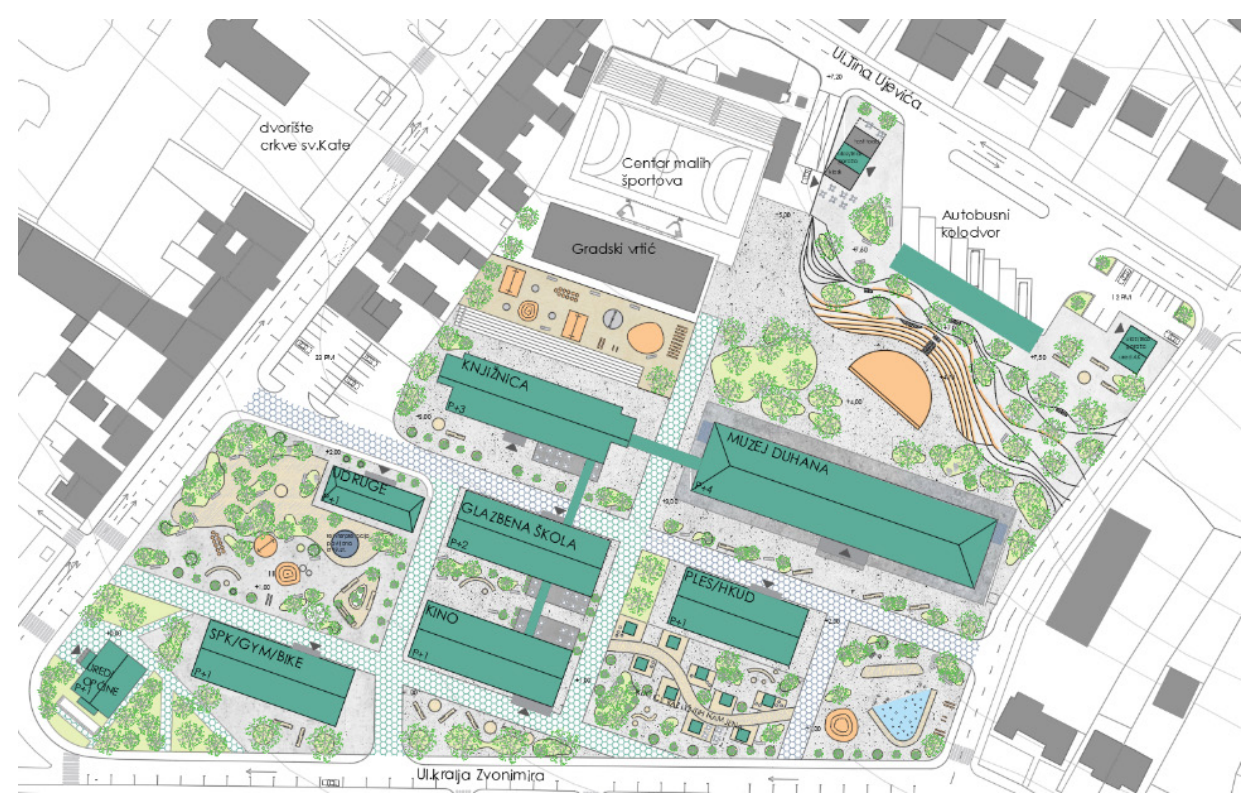

Slika 12. Diplomski rad - prijedlog obnove Duhanske stanice Ljubuški, situacijski nacrt (Izradila: $L j$. Rupčić)

Nekadašnji transportni mostovi, koji su magazine povezivali na razini njihovih prvih etaža, uočeni su kao veliki potencijal za prostorno povezivanje te za multifunkcionalno i fleksibilno korištenje novih sadržaja. Tako su povezani zgrada muzeja i knjižnica, knjižnica i plesna škola te plesna škola i multifunkcionalna dvorana. Zbog značajnih konstruktivnih

\footnotetext{
7 Magazin br. 4 srušen he 2003. godine te je na njegovom mjestu izgrađena bespravna stambena zgrada. Stoga je u ovom prijedlogu rješenja planirano rušenje stambenog objekta.
} 
oštećenja i generalno lošeg zatečenog stanja, predlaže se rušenje postojećih mostova i izvedba novih na njihovom mjestu. Oblikovni izričaj mostova bi bio suvremen, poštujući zatečenu značajku da se uvijek jasno iščitava novi sloj gradnje unutar kompleksa (Slika 13).
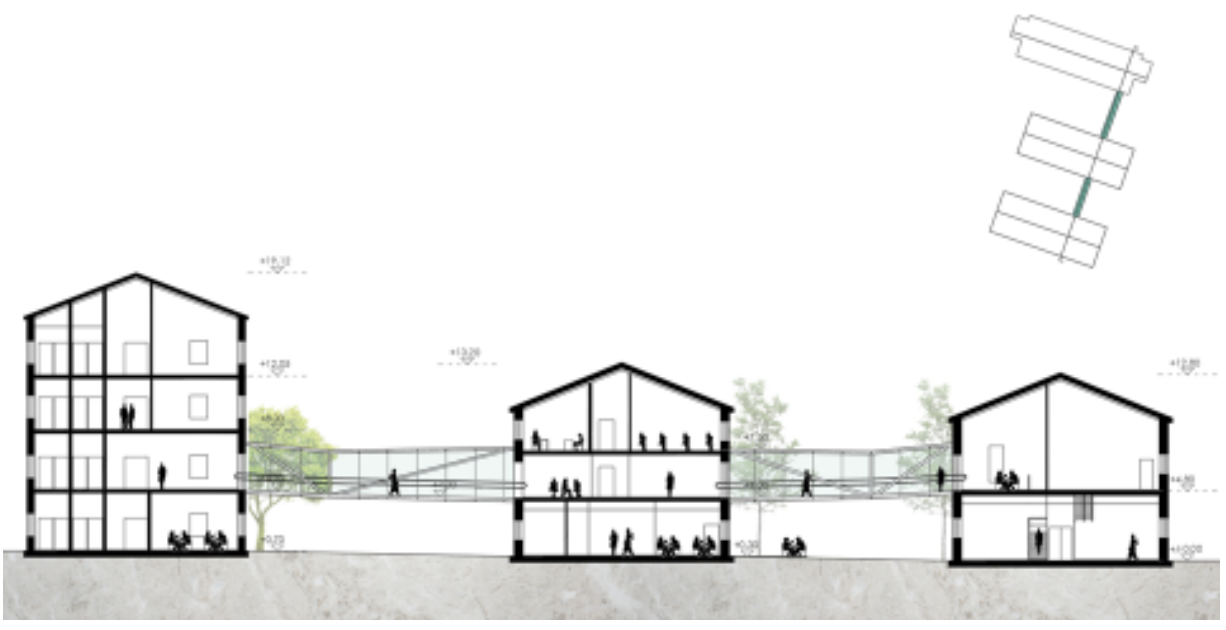

Slika 13. Diplomski rad - prijedlog obnove Duhanske stanice Ljubuški, poprečni presjek kroz magazine (Izradila: Lj. Rupčić)
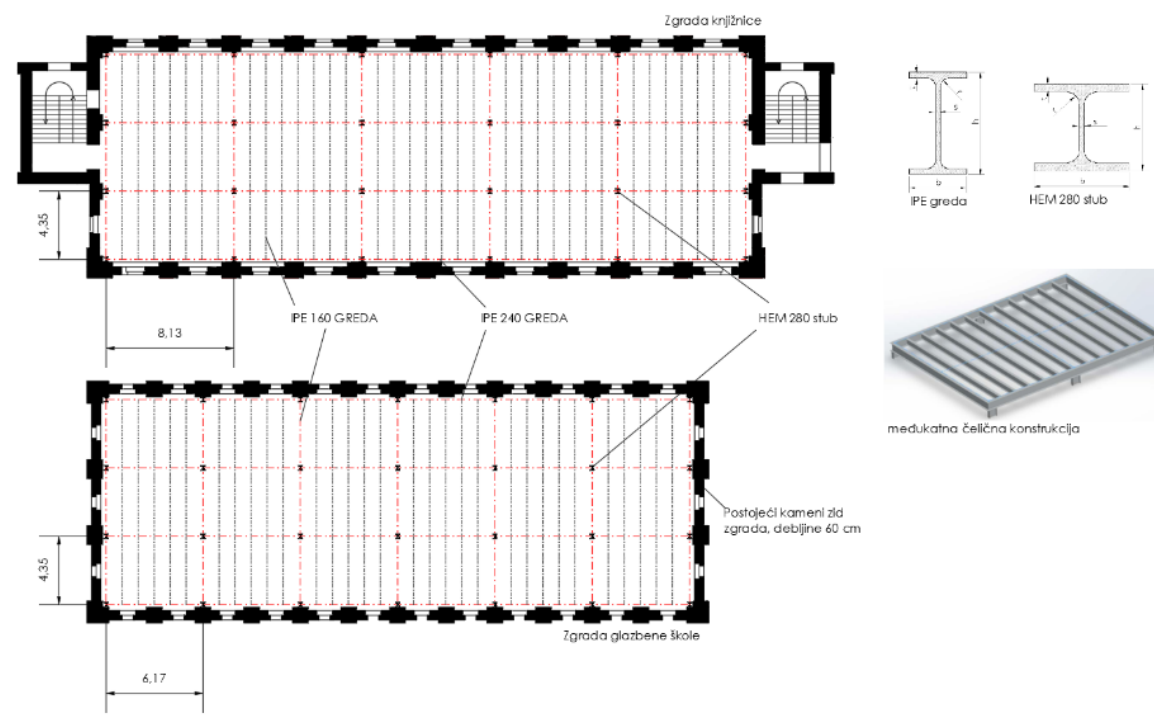

Slika 14. Diplomski rad - prijedlog obnove Duhanske stanice Ljubuški, prijedlog konstruktivne sanacije (Izradila: Lj. Rupčić) 
Projektom je velika pažnja posvećena adekvatnom uređenju vanjskog prostora između građevina, čime bi se osiguralo njegovo svakodnevno korištenje. Cilj je bio povezati sjeverni dio, dakle, autobusni kolodvor, s kompleksom nekadašnje duhanske stanice te aktivirati prostor između zgrada sadržajima kao što su park s amfiteatrom (za ljetno kino, predstave i ostala javna događanja), dječja igrališta, urbani vrtovi i sl. Koncept uređenja vanjskog prostora temelji se na uspostavljanju jasnih pješačkih pravaca postavljenih tangencijalno na postojeće zgrade i formiranju različitih karaktera. Sve otvorene plohe su adekvatno ozelenjene i opremljene urbanom opremom u skladu s planiranim korištenjem.

Same zgrade bile bi u potpunosti konstruktivno obnovljene izvedbom nove međukatne i krovne čelične konstrukcije od rastera PE i HEM greda te adekvatnom konstruktivnom sanacijom zidova (injektiranjima, izvedbom novih $A B$ ukruta i sl.). Gabaritno su sve građevine sačuvane u izvornim dimenzijama, ali su uvedene nove vrste otvora kako bi se prostor prilagodio novim sadržajima (Slika 14).

\section{Zaključak}

Duhanska proizvodnja imala je ogromno značenje u prošlosti na području Ljubuškog i nosila je skoro cijelo gospodarstvo. Osim gospodarske važnosti, veoma je važno istaknuti i socijalnu kategoriju proizvodnje duhana jer je duhan brojnim obiteljima dugi niz godina predstavljao glavni izvor dohotka. Duhan je bio kultura od koje se živjelo i s kojom se živjelo. U njegovu uzgoju i proizvodnji sudjelovali su svi članovi obitelji, kako oni radno sposobni, tako i djeca i starije osobe te su mnoge obitelji u cijeloj općini i okolici živjele od uzgoja duhana [11]. Koncem 20. stoljeća dolazi do stagnacije, a u 21. stoljeću do potpunog gašenja duhanske proizvodnje u Hercegovini [12].

Analizom Duhanske stanice u Ljubuškom pronađene su značajke svih elemenata koji su obilježili razvoj duhanskih stanica te kompleks predstavlja reprezentativni uzorak ukupnog nasljeđa duhanske industrije $u$ Hercegovini. Navedeno ukazuje na važnost procesa revitalizacije duhanskih stanica koje su sve trenutno van pogona i prepuštene propadanju, a predstavljaju veliki prostorni i socio-ekonomski kapacitet od presudne važnosti za razvoj gradova i općina u kojima su smještene. Osnovni povod za ovo istraživanje bio je da se ukaže i zabilježi stanje Duhanske stanice u Ljubuškom, u nadi da će doći do promjena u budućnosti te da će istraživanje tome poslužiti. U tu svrhu, umjesto klasičnog zaključka izrađena su dva završna poglavlja kojima će se nastojati vrednovati analizirano i dati smjernice za budući razvoj. 


\subsection{Vrednovanje}

Analizom građe preuzete iz Državnog arhiva Bosne i Hercegovine vidljiv je nastanak Duhanske stanice, iz koje je moguće ustanoviti sve njene faze izgradnje, kao i činjenicu da je nastala na gotovo neizgrađenom području ispod tadašnjeg grada, odnosno na njegovoj periferiji. Osim toga, proučavanjem izvornih nacrta saznajemo da numeracija magazina za čuvanje listova duhana odgovara etapnosti njihove izgradnje. Isti arhiv sadrži cjelovite projekte dvaju upravnih zgrada te tipski nacrt magazina, koji je bio projektiran kao tipski magazin za duhanske stanice na području cijele Bosne i Hercegovine i prema kojemu su se izvele prve četiri magazinske zgrade. Po ovom tipskom projektu izgrađene su zgrade skladišta u stanicama duhana u Čapljini i Širokom Brijegu. Magazin br. 5 je bio varijacija tipa, ali predstavlja individualan projekt.

Danas Magazin br. 4 više ne postoji, a na njegovu se mjestu nalazi višestambena nenaseljena zgrada bespravne izgradnje; Magazin br. 5 je izgorio, a Magazin br. 3 je izmijenjen promjenom krova u limeni i dogradnjom betonskog dijela nosivog zida neposredno ispod krova.

Visoka kvaliteta izvedbe gradnje građevina, stupanj uređenosti vanjskog prostora i veličina sklopa svjedoče o značenju koje je kompleks imao. Izrađena povijesna i arhitektonsko-urbanistička analiza razvoja kompleksa s valorizacijom arhitektonsko-urbanističkih kvaliteta može poslužiti kao podloga za rad na daljnjim procesima revitalizacije ovog središnje gradskog prostora koji ima potencijal generiranja novog urbaniteta grada Ljubuškog, ali i kao podloga za izradu analiza ostalih napuštenih otkupnih stanica po Hercegovini.

\subsection{Smjernice}

A) Duhanske stanice predstavljale su izdvojenu cjelinu unutar gradskog tkiva, što je, s obzirom na strogo kontrolirani proces prerade duhana, bilo i potrebno. Stoga je pri revitalizaciji ovih kompleksa potrebno sagledati širi urbani kontekst i pokušati uspostaviti veze s postojećim prometnim i pješačkim pravcima kako bi se omogućila što kvalitetnija integracija u gradsku cjelinu.

U skladu s time, potrebno je posebnu pažnju posvetiti oblikovanju vanjskih površina i prilagođavanju njihova korištenja u novu, javnosti dostupnu svrhu. Također je potrebno napraviti i valorizaciju planiranog i novonastalog zelenila u svrhu ostvarivanja pogodnih mikroklimatskih uvjeta te očuvanja bioraznolikosti.

B) Odabir adekvatnog sadržaja ključan je element u prenamjeni, ali i procesu revitalizacije kompleksa Duhanske stanice. S obzirom na uniformiranost i racionalnost projekata, a koji se temelje na uspostavljenom rasteru u skladu sa odabranim materijalom gradnje, sve 
zgrade predstavljaju svojevrsne prazne kutije u koje je moguće umetnuti sadržaje po želji. Pritom se društveno-kulturni sadržaji nameću kao prvi izbor s obzirom da isti imaju najveću fleksibilnost u korištenju prostora, kao i najveću mogućnost da se prilagode zatečenom stanju.

C) Sve skladišne zgrade Duhanske stranice pravilne su geometrije tlocrtno izduženog pravokutnika. Unutrašnji prostor pojedinog kata definiran je rasterom stupova i obodnim zidovima, perforiranim unificiranim prozorima. Specifična je i međukatna visina, proizašla iz korištenja drvene građe u prvim fazama te, kasnije, korištenjem armiranobetonske konstrukcije. S obzirom na specifičnost arhitektonskog oblikovanja, proizašlog iz potrebe kontrole mikroklimatskih uvjeta sušenja duhana, zgrade imaju vrlo prepoznatljiv vanjski izgled. Pri prenamjeni je potrebno sagledati i uvažiti navedeno oblikovanje, a kako bi se očuvale osnovne značajke objekata.

D) Usklađenost oblikovanja s klimatskim uvjetima svakako je nešto što je potrebno dodatno istražiti s termodinamičkog aspekta. Svjedoci smo vremena gdje se traži visoka energetska učinkovitost i što viša održivost gradnje. Stoga je osiguravanje kvalitetnih mikroklimatskih uvjeta unutar građevine kroz gradnju jedan od ključnih aspekata, a građevine Duhanske stanice to su logično načelo imale utkano u svoj dizajn. Korištenje suvremenih rješenja je dobrodošlo, no potrebno ih je oprezno primijeniti kako se ne bi narušila, već nadogradila osnovna kvaliteta oblikovanja građevina.

Zahvala. Rad se temelji na istraživačkom dijelu diplomskog rada pod naslovom "Duhansko blago - Obnova Duhanske stanice Ljubuški" (diplomantica: Ljilja Rupčić, mentor: izv. prof. art. Nikola Popić, komentor: doc. dr. sc. Hrvoje Bartulović) obranjenog 9. 2. 2021. na Fakultetu građevinarstva, arhitekture i geodezije u Splitu., Prikazana istraživanja djelomično su podržana projektom KK.01.1.1.02.0027 - projekt sufinanciran iz Državnog proračuna Republike Hrvatske i Europskog fonda za regionalni razvoj unutar Operativnog programa Konkurentnost i kohezija.

\section{Literatura}

[1] Beljo, J. gl. ur. (2017.) Zbornik radova s međunarodnog znanstveno-stručnog skupa „Duhan u Bosni i Hercegovini - jučer, danas i sutra”. Federalni agromediteranski zavod, Mostar, Bosna i Hercegovina

[2] Vukojević, I., Beljo, J., Barišić Marenić, Z. (2017.) Utjecaj tehnologije obrade duhana na prostornu organizaciju duhanskih stanica na području Hercegovine u Beljo, J. (gl. ur.) Zbornik radova s međunarodnog znanstvenostručnog skupa „Duhan u Bosni i Hercegovini - jučer, danas i sutra”. Federalni agromediteranski zavod, Mostar, Bosna i Hercegovina, str. 266- 279 
[3] Gašpar, K. (2011.) Revitalizacija prostora bivše Duhanske stanice u Ljubuškom (diplomski rad), Arhitektonski fakultet u Zagrebu

[4] Državni arhiv Bosne i Hercegovine

[5] Stare fotografije Ljubuškog iz naše arhive. http://ljubusaci. com/2020/10/29/stare-fotografije-ljubuskog-iz-nase-arhive/ (29.11.2020.)

[6] Arhiv općine Ljubuški

[7] Vukojević, I., Barišić Marenić, Z., Bojanić Obad Šćitaroci, B. (2019.) Urbanističko-arhitektonski sklop Duhanske stanice „Vaga“ u Metkoviću Prostor, 1(57): 100-117

[8] Alternativna Liga Ljubuški. http://alternativnaliga.blogspot.com/ (09.12.2020.)

[9] Prostorni plan Općine Ljubuški objavljen u listopadu 2015. za period u razdoblju od 2015.-2025.

[10] Rupčić, Lj. (2021.) Duhansko blago - obnova Duhanske stanice Ljubuški (diplomski rad - mentor: N. Popić), Fakultet građevinarstva, arhitekture i geodezije u Splitu

[11] Beljo, J., Ivanković, M., Herceg, N.. (2017.). Gospodarsko i socijalno značenje uzgoja duhana u Hercegovini u Beljo, J. (gl. ur.) Zbornik radova s međunarodnog znanstveno-stručnog skupa „Duhan u Bosni i Hercegovini - jučer, danas i sutra". Federalni agromediteranski zavod, Mostar, Bosna i Hercegovina, str. 70-82

[12] Ivanković, M., Markić, B., Đemidžić, M. (2017.) Ekonomski, tržišni i tehnološki aspekti nestanka proizvodnje duhana u Hercegovi u Beljo, J. (gl. ur.) Zbornik radova s međunarodnog znanstveno-stručnog skupa „Duhan u Bosni i Hercegovini - jučer, danas i sutra". Federalni i agromediteranski zavod, Mostar, Bosna i Hercegovina, str. 83-100 
